\title{
Management Factors Across Entrepreneurial Business Sectors in Emerging Economies of Nigeria and South Africa
}

\author{
Charles Temitope Jegede*, Folashade Oyeyemi Akinyemi, Temitope Favour Jiboye, \\ Michael Olufemi Akinyosoye
}

Institute for Entrepreneurship and Development Studies, Obafemi Awolowo University, Ile-Ife, Nigeria

\section{Email address:}

charlesjegede@gmail.com (C. T. Jegede), queenesthershade@gmail.com (F. O. Akinyemi), tfjiboye@gmail.com (T. F. Jiboye), mikeakinyosoye@gmail.com (M. O. Akinyosoye)

*Corresponding author

\section{To cite this article:}

Charles Temitope Jegede, Folashade Oyeyemi Akinyemi, Temitope Favour Jiboye, Michael Olufemi Akinyosoye. Management Factors Across Entrepreneurial Business Sectors in Emerging Economies of Nigeria and South Africa. American Journal of Management Science and Engineering. Vol. 4, No. 3, 2019, pp. 39-48. doi: 10.11648/j.ajmse.20190403.11

Received: April 18, 2019; Accepted: June 11, 2019; Published: July 10, 2019

\begin{abstract}
The paper examined strategic management factors that promote entrepreneurial activities across some selected business sectors in the emerging economies of Nigeria and South Africa. Specifically, it identified the most prominent management factor in each economy, and the most crucial in each sector. We proposed that by examining these factors across sectors, in two emerging economies, management factors that enhance entrepreneurial activities would be industry specific and dissimilar. The sample size consisted of a total of 1200 entrepreneurs that aged between 18 to 64 years in Lagos and Johannesburg. The data were cleaned and analyzed using STATA Purposive sampling technique. Principal Component Analysis (PCA) was used to identify the most crucial policy factor (s) in each sector, Also, Chi-square test was used to show the association between the variables, and Cronbach's Alpha was employed to test the internal consistency and reliability of some of the critical indicators. Research findings suggested that the management factors that enhanced entrepreneurial activities differ across business sectors. Some management factors are more crucial in some sectors than others. In Nigeria, marketing strategy was the principal component in all except service sector whereas in South Africa, recruitment policy was the principal component in all the seven sectors. For the pooled data, however, marketing strategy was the principal component in four out of seven sectors. Two factors, namely, Organizational Structure and recruitment policy were equally crucial in the telecommunication sector while accounting policy and recruitment policy were the principal components in metal and service sectors, respectively. The study suggests that entrepreneurial firms in Lagos needs to concentrate more on their marketing strategies while those in South Africa needs to focus more on their recruitment procedures for better performance.
\end{abstract}

Keywords: Entrepreneurship, Strategic, Industry, Marketing, Recruitment, Policy

\section{Introduction}

Studies over the past years have shown that the way a business is run determines how far it would go [1-3]. Studies have also shown that, besides the entrepreneurial personality factor, other variables such as the nature and existence of management teams determine the outcome of business ventures [4-6]. Also, strategic planning and good management practices help businesses grow. Effective workforce, good book keeping practices, and leadership styles, are some of the factors found helpful in sustaining businesses [7]. For effective workforce, some entrepreneurs provide good compensation packages for their employees [2]. Some also provide flexible and family-friendly working arrangements such as shifts, maternity leave, and study leave for their employees [8-9]. Furthermore, studies have shown that other organizational factors such as business networks, market survey, and research \& development, are helpful in 
sustaining businesses [10-11] but have not explained their levels of importance in various business sectors. The literature is replete with studies that identified these and so many management factors that help promote businesses but the question is: Are all these factors equally important in every business sector? This study, for clarity purpose, will examine six commonly discussed factors in literature namely; organization structures, accounting policy, business network, recruitment policy, marketing strategy, research and development. It will examine these strategic management factors across business sectors that enhance entrepreneurial activities, their relative importance, and the most crucial in each sector in two emerging African economies of Nigeria and South Africa. In doing this, the study will attempt to: examine the management factors adopted in each sector, identify the most crucial management factor(s), and compare the findings at each level of analysis.

\section{Literature Review}

\subsection{Entrepreneurship \& Management Factors}

Establishing and managing a viable business, especially in emerging economies, is a herculean task. Though entrepreneurs are unique individuals with special skills and innovative abilities, they still need some form of managerial prowess to navigate their businesses from the start-up to fullblown. The organization's key strategic management decisions such as organizational structure, market analysis, accounting policies, strategy formulation, product diversification, and industry positioning, to mention but a few, are majorly the entrepreneurs' and business owners' responsibilities and ultimately originate from them [12-15]. These key strategic management decisions are referred to as management factors and include various types of methods ranging from the recruitment policies and remuneration methods adopted by entrepreneurs in order to grow their businesses [16, 17]. Examples from some renowned businesses show the importance of management factors in business organizations. For instance, as a growing company, advertising was one of the key factors in Coca cola's success [18-20]. Also, an Italian leading cement manufacturer, Italcementi, moved from a closed to an open innovation system, and made tremendous progress [21, 22]. Important revamping works were implemented to make the Italian industrial network more efficient. Furthermore, new research and innovation center was inaugurated. The company also used knowledge management to improve its subsidiary performance [23].

On the other hand, a once growing and dynamic organization, Enron Corporation, nosedived because of poor management practices. Eventually, Enron plummeted and was declared bankrupt in December 2001. This incidence also questioned the accounting practices of many corporations in the United States and led to the enactment of the Sarbanes-Oxley Act in 2002. The incidence also affected the greater business world by causing the dissolution of the
Arthur Anderson accounting firm [24, 25]. In essence, the management factors such as marketing strategies, accounting policies, and organizational structures adopted in the aforementioned businesses determined the boom and doom of each business.

\subsection{Entrepreneurial Activities in Developed and Emerging Economies}

Entrepreneurship has been the root cause of most industrialization and it has also been rejuvenating some industrialized economies. Entrepreneurship has been found to involve three elements namely: Proactiveness, Risk-taking and innovativeness/invention [7]. Risk-taking involves going into business to commercialise the product/service. The process of entrepreneurship is incomplete without commercialisation [7]. Good support systems, personality factors and management factors have also been found to contribute immensely to the entrepreneurial success in industrialised nations [26]. Business partners, good management practices, and prior experiences in paid employment, have also helped them to sustain entrepreneurial businesses [27]. Prominent among the factors associated with entrepreneurial success in emerging economies are personality factors, entrepreneurial motives, and social networks [28]. These are nations with relatively lower gross national product, lower per capita income and lower gross domestic product when compared with the industrialized nations [29].

\subsection{Business Sectors Classifications}

The breakdown of economic activities into three sectors, developed by Allan G. B Fisher, comprised of the primary, secondary and tertiary sectors [30]. The primary sector involves the extraction of raw materials and agricultural activities; the secondary sector consists of the manufacturing and construction sector; while the tertiary sector comprises of commerce and services. Further extension of the sector classification with five sectors includes the quarternary and quinary, which are closely linked with the services of the tertiary sector. In these models, the quaternary sector of the economy consists of intellectual activities often associated with technological innovation and it is sometimes called the knowledge economy. Activities associated with this sector include education, culture, government, scientific research, libraries, and information technology. Some economists further subdivided the quaternary sector into the quinary sector which includes the highest levels of decision making in a society or economy. This sector includes top executives or officials in such fields as healthcare, universities, government, science, nonprofit, culture and the media. It may also include police and fire departments, which are public services as opposed to profit-making enterprises. Economists sometimes also include domestic activities (duties performed in the home by a family member or dependent) in the quinary sector. The Global Industry Classification Standard (GICS) developed in 1999 by Morgan Stanley Capital International 
(MSCI) and Standards \& Poor (S\&P) organizes companies into industrial groupings based on similar production processes, similar products, or similar behavior in financial markets [31]. The GICS structure consists of 11 sectors, 24 industry groups, 68 industries and 157 sub-industries into which S\&P has categorized all major public companies. But for this study, the seven sector classification would be adopted because of the ease of comparison and it reflects all the economic activities in both Nigeria and South Africa

The seven sector classification divides economic activities into seven major lines of business namely (1) food, beverage and tobacco industry; (2) textile, textile products and weaving apparels; (3) wood, wood products and paper; (4) pharmaceuticals, chemicals, and rubber products; (5) metals, iron and steel products; (6) telecommunication and information technology; and (7) service industries.

\subsection{Theoretical Review}

Two theories, which are common and relevant to this study, are Henry Mintzberg's and contingency theory of organizational structure and economic model of organizational efficiency [32]. Henry Mintzberg's contingency theory of organizational structure describes, and determines, the line of authority and flow of communication within an organization [32-34]. Economic model highlights the effect of organizational efficiency. The model asserts that organizational efficiency leads to profitability in the short run and survival in the long run [35 \& 36]. Both theories support the notion that businesses that innovate are more likely to grow and survive [37-39]. Innovation is often a product of research and development [40]. The innovation process allows entrepreneurs to remain a step ahead of other competitors and therefore remain in business. Most times, entrepreneurs create barriers to competition by regularly advancing their production processes and outputs. Some entrepreneurs produce a wide range of products in order to satisfy and retain more customers.

\section{Methodology}

The study was conducted in the economic hub of two African emerging economies, Lagos in Nigeria and Johannesburg in South Africa. Lagos is Nigeria's commercial center where most entrepreneurial activities take place [4142]. And similarly, Johannesburg is South Africa's commercial center where most entrepreneurial activities take place. It is the largest city in South Africa and is the provincial capital of Gauteng [43-44]. Although entrepreneurial orientation of Nigerians have been found to be low [7], no information on South Africa

The target population comprises of entrepreneurs in the two capital cities. The sample size consisted of entrepreneurs in Lagos and Johannesburg. This comprised of adults between 18-64 years as adopted by the Global Entrepreneurship Monitor [29]. A total of 1200 questionnaires were administered. Since the estimated figures obtained through extant literature revealed that there are more entrepreneurs in Lagos than in Johannesburg, 550 questionnaires were administered in Johannesburg and 650 were administered in Lagos.

The entrepreneurs were asked to identify the management factors adopted in growing their businesses. They were also asked to indicate the relative importance of the management factors using a five point Likert scale from most crucial to not crucial. The data collected were cleaned and analyzed using STATA Purposive sampling technique to select the sample size because of the lack of pre-determined population [45-47]. Principal Component Analysis (PCA) was used to identify the most crucial policy factor(s) in each sector, Also, Chi-square test was used to show the association between the variables, and Cronbach's Alpha was employed to test the internal consistency and reliability of some of the critical indicators. Chi-square is a statistical test used to show the association between variables, and also to compare the expected results with the actual. If the differences between the expected and actual results are large, it means that the differences in the results did not occur by random chance but were caused by some factors. Hence, the results are said to be statistically significant.

This study was conducted in strict compliance with social research ethics such as voluntary consent, anonymity, and confidentiality. Consent Paper was obtained from the University Ethics Committee before embarking on the study. Covering letter was given to prospective respondents and the information obtained was treated with utmost confidentiality. For construct validity, the key concepts were properly defined and the operational measures identified. Cronbach's Alpha was used to test for reliability [48, 49). The instruments were also pre-tested to ensure that the contents were well understood. The study adopted the seven-sector theory on industrial classification, which comprises of (1) food, beverage and tobacco industry; (2) textile, textile products and weaving apparels; (3) wood, wood products and paper; (4) pharmaceuticals, chemicals, and rubber products; (5) metals, iron and steel products; (6) telecommunication and information technology; and (7) service industries.

\section{Research Results and Discussion}

\subsection{Background Information on Entrepreneurs and Management Factors Adopted in Each Sector}

Table 1 presents the background information on the respondents and the seven major classifications of entrepreneurial activities in national economies namely: food, textile, pharmaceuticals, metal, wood, telecommunication and services. The three most populous sectors in both economies were the service, food, and textile sectors, respectively [50]. The service sector $(30 \%$ in Nigeria and $47 \%$ in South Africa) comprised of businesses such as hairdressing salons, medical practitioners, and day care centers. Restaurant owners, fruits, and raw food sellers dominated the food sector $(17 \%$ in Nigeria and $19 \%$ in South Africa). The textile businesses (13\% in Nigeria and $15 \%$ in 
South Africa) included cloth manufacturing companies, dressmakers and sellers. In terms of ownership, most of the entrepreneurs in both countries were male $(63 \%$ in Nigeria and $62 \%$ in South Africa). The median age of the sampled entrepreneurs was very close in both countries (31 years in Nigeria compared with 32 years in South Africa). The age distribution leaned favorably towards the younger age range of 18-33years constituting relatively more than half of the sampled entrepreneurs (53\% in Nigeria and 51\% in South Africa). More than one-fourth are aged 34-41 years, and only about $6 \%$ in Nigeria and $7 \%$ in South Africa were aged 50 years or more.

\subsubsection{Factor Loadings and Reliability Coefficients of Management Factors}

Table 2 presents the holistic view of the internal structure, reliability estimate, and variance of the management factors in Nigeria and South Africa. While Table 3 presents the internal structure, reliability estimate, and variance of the management factors across the selected business sectors. The crux of the findings is that the management factors for the business sectors in emerging economies do not carry equal weights. Some management factors are more important than others.

Table 1. Distribution by information on business sectors.

\begin{tabular}{|c|c|c|c|c|}
\hline \multirow{2}{*}{ VARIABLES } & \multicolumn{2}{|l|}{ NIGERIA } & \multicolumn{2}{|l|}{ SOUTH-AFRICA } \\
\hline & FREQUENCY N=609 & PERCENT & FREQUENCY N=539 & PERCENT \\
\hline \multicolumn{5}{|l|}{ Gender } \\
\hline Male & 385 & 63.2 & 336 & 62.3 \\
\hline Female & 224 & 36.8 & 203 & 37.7 \\
\hline \multicolumn{5}{|l|}{ Age in Years } \\
\hline $18-24$ & 80 & 13.3 & 65 & 12.1 \\
\hline $25-33$ & 238 & 39.6 & 209 & 38.9 \\
\hline $42-49$ & 87 & 14.5 & 70 & 13.0 \\
\hline $50-57$ & 24 & 4.0 & 27 & 5.0 \\
\hline $58-65$ & 13 & 2.2 & 12 & 2.2 \\
\hline Median Age & 31.2 years & & 32.4 years & \\
\hline \multicolumn{5}{|l|}{ Business Sectors } \\
\hline Food & 104 & 17.4 & 103 & 19.3 \\
\hline Textile & 77 & 12.9 & 80 & 15.0 \\
\hline Pharmaceuticals & 43 & 7.2 & 7 & 1.3 \\
\hline Metal & 75 & 12.5 & 25 & 4.7 \\
\hline Telecommunication & 74 & 12.4 & 49 & 9.2 \\
\hline Service & 182 & 30.4 & 250 & 46.7 \\
\hline
\end{tabular}

Source: Field work, 2018

In Table 3 for instance, only three of the management related variables (research and development, business network, and marketing strategy) recorded strong effect in Nigeria compared to one (recruitment policy) in South Africa and none in the pooled dataset.

Table 2. Internal structure and domain of management factors in Nigeria and South Africa.

\begin{tabular}{|c|c|c|c|c|c|c|}
\hline \multirow{2}{*}{ Two Countries } & \multicolumn{2}{|l|}{ Nigeria } & \multicolumn{2}{|l|}{ South Africa } & \multicolumn{2}{|l|}{ Both Countries } \\
\hline & Factor loading & Alpha/Variance & Factor loading & Alpha/Variance & Factor loading & Alpha/Variance \\
\hline \multicolumn{7}{|l|}{ Management } \\
\hline Accounting Policy & -0.04 & & 0.41 & & 0.35 & \\
\hline Organisational Structure & 0.12 & & 0.49 & & 0.43 & \\
\hline Recruitment Policy & -0.07 & 0.24 & 0.55 & 0.29 & 0.48 & 0.28 \\
\hline Business Network & 0.57 & 87.1 & 0.26 & 88.1 & 0.36 & 87.1 \\
\hline Research \& Development & 0.50 & & 0.36 & & 0.40 & \\
\hline Marketing Strategy & 0.64 & & 0.31 & & 0.42 & \\
\hline
\end{tabular}

Source: Field work, 2018

As shown in Table 4, the management factors generally recorded weak effects in all the sectors in both economies. None of the sectors had strong effects in all the six management factors. Sectors such as Nigeria's textile and pharmaceuticals, and South Africa's wood sector recorded only one management factor as having strong effect. Other sectors such as South Africa's food, textile, telecommunication, and service sectors recorded strong effects in two management factors. Most of the businesses were small and medium scale, and most of the entrepreneurs reported that they did not adopt standardized management strategies because of the size of their businesses. 
Table 3. Cross-tabulation of management actors in Nigeria and South Africa.

\begin{tabular}{|c|c|c|c|c|c|c|}
\hline \multirow{2}{*}{ Sectors } & \multicolumn{2}{|l|}{ Nigeria $(n=598)$} & \multicolumn{2}{|c|}{ South Africa $(n=535)$} & \multicolumn{2}{|c|}{ Both Countries $(n=1133)$} \\
\hline & Percent/p-value & Chi-square & percent/p-value & Chi-square & percent/p-value & Chi-square \\
\hline \multicolumn{7}{|l|}{ Management Factors } \\
\hline Accounting Policy & $2.5 / 0.00$ & 55.97 & $5.1 / 0.01$ & 10.70 & $3.7 / 0.00$ & 42.09 \\
\hline Organizational Structure & $2.8 / 0.00$ & 53.73 & $2.8 / 0.01$ & 10.67 & $2.8 / 0.00$ & 41.48 \\
\hline Recruitment Policy & $0.5 / 0.00$ & 53.61 & $1.3 / 0.01$ & 10.65 & $0.9 / 0.00$ & 41.36 \\
\hline Business Network & $10.0 / 0.00$ & 54.11 & $13.6 / 0.00$ & 10.82 & $11.7 / 0.00$ & 42.10 \\
\hline Research \&Development & $2.2 / 0.00$ & 53.69 & $6.7 / 0.01$ & 10.72 & $4.3 / 0.00$ & 41.58 \\
\hline
\end{tabular}

Note: Significant at $\mathrm{p}<.05$

Source: Field work, 2018

\subsubsection{Distribution Pattern and Statistical Significance of Management Factors Across Business Sectors}

The respondents were asked to rank the management factors by highlighting five management factors enhancing their businesses out of the six management factors listed in the questionnaire. Table 4 presents the bivariate distribution of management factors with emphasis on both the distribution pattern and statistical significance of each variable within the domain. As shown in Table 4, without controlling for business sectors, all the variables were statistically significant $(\mathrm{p}<0.05)$ across the two countries and for the combined data set.

A major striking point in Table 4 is the fact that the aggregate measures of the management factors align with the literature review sections where all the factors were reported as important for entrepreneurial activities [51 \& 52]. The previous studies, flagging the importance of these management factors, were conducted independently, at different points in time, and were not specific about the business sectors where these factors were more pivotal. Hence, without controlling for the sectors, the holistic view as shown in Table 3 is that all the management factors are equally significant.

Table 5 shows a cross-tabulation of management factors by selected business sectors in Nigeria and South Africa. When control variables such as sectors are introduced, as shown in Table 5, interesting insights emerged. For instance, only accounting policy and business network were statistically significant in Nigeria's food sector. There were no other statistically significant management factors in other sectors. In South Africa, all the six management factors were statistically significant at the service sector research \& Development and accounting policy were statistically significant at telecommunication sector. And in the pooled data, all the six management factors were statistically significant at the service sector and only business network was statistically significant in the food sector. Considering the holistic distribution patterns in Table 5, among management factors, marketing strategies $(13 \%$ in Nigeria and $25 \%$ in South Africa) and business network (10\% in Nigeria and $14 \%$ in South Africa) were the two main variables with the highest frequencies. Marketing strategy was the most frequently adopted management factor in each country, and in the pooled data. Moreover, the entrepreneurs in both emerging economies attested to the fact that, because of the high level of competition, there was the need to intensify innovative marketing strategies in order to attract as many customers as possible.

Furthermore, the table 5 shows the percent/p-value of the management factors enhancing businesses in the selected business sectors in Nigeria and South Africa.

These data suggest that marketing strategy was the frequently adopted management factor in virtually all business sectors in South Africa except for pharmaceutical sector. In Nigeria, some variations exist as business network had the highest frequencies in three out of the seven sectors. The figures, however, confirm that the various combinations of management factors adopted in the selected sectors are basically not the same.

\subsection{Crucial Management Factors Adopted in Each Business Sector}

Having confirmed that the management factors are not equally important in all the sectors, the second objective was to examine their relative importance in order to identify the most crucial management factor(s) adopted in each sector.

Table 4. Internal structure and domain of management factors in selected business sectors in Nigeria and South Africa.

\begin{tabular}{|c|c|c|c|c|c|c|c|c|c|c|c|c|c|}
\hline \multirow[b]{2}{*}{ Sectors } & \multicolumn{2}{|l|}{ Food } & \multicolumn{2}{|l|}{ Textile } & \multicolumn{2}{|l|}{ Wood } & \multicolumn{2}{|c|}{ Pharmaceutical } & Metal & \multicolumn{2}{|c|}{ Telecommunication } & \multicolumn{2}{|l|}{ Services } \\
\hline & $\begin{array}{l}\text { Factor } \\
\text { loading } \\
\end{array}$ & $\begin{array}{l}\text { Alpha/ } \\
\text { Variance }\end{array}$ & $\begin{array}{l}\text { Factor } \\
\text { loading } \\
\end{array}$ & $\begin{array}{l}\text { Alpha/ } \\
\text { Variance } \\
\end{array}$ & $\begin{array}{l}\text { Factor } \\
\text { loading } \\
\end{array}$ & $\begin{array}{l}\text { Alpha/ } \\
\text { Variance }\end{array}$ & $\begin{array}{l}\text { Factor } \\
\text { loading } \\
\end{array}$ & $\begin{array}{l}\text { Alpha/ } \\
\text { Variance }\end{array}$ & $\begin{array}{l}\text { Factor Alpha/ } \\
\text { loading Variance }\end{array}$ & $\begin{array}{l}\text { Factor } \\
\text { loading } \\
\end{array}$ & $\begin{array}{l}\text { Alpha/ } \\
\text { Variance }\end{array}$ & $\begin{array}{l}\text { Factor } \\
\text { loading } \\
\end{array}$ & $\begin{array}{l}\text { Alpha/V } \\
\text { ariance }\end{array}$ \\
\hline $\begin{array}{l}\text { Nigeria } \\
\text { Management }\end{array}$ & & & & & & & & & & & & & \\
\hline $\begin{array}{l}\text { Accounting } \\
\text { Policy }\end{array}$ & - & & -0.30 & & - & & -0.26 & & 0.71 & -0.11 & & -0.13 & \\
\hline $\begin{array}{l}\text { Organiz. } \\
\text { Structure }\end{array}$ & 0.61 & & 0.50 & & -0.23 & & 0.02 & & - & 0.67 & & 0.03 & \\
\hline $\begin{array}{l}\text { Recruitment } \\
\text { Policy }\end{array}$ & - & & - & & -0.15 & & -0.17 & & - & 0.65 & & - & \\
\hline
\end{tabular}




\begin{tabular}{|c|c|c|c|c|c|c|c|c|c|c|c|c|c|c|}
\hline \multirow[b]{2}{*}{ Sectors } & \multicolumn{2}{|l|}{ Food } & \multicolumn{2}{|c|}{ Textile } & \multicolumn{2}{|c|}{ Wood } & \multicolumn{2}{|c|}{ Pharmaceutical } & \multicolumn{2}{|c|}{ Metal } & \multicolumn{2}{|c|}{ Telecommunication } & \multicolumn{2}{|c|}{ Services } \\
\hline & $\begin{array}{l}\text { Factor } \\
\text { loading }\end{array}$ & $\begin{array}{l}\text { Alpha/ } \\
\text { Variance }\end{array}$ & $\begin{array}{l}\text { Factor } \\
\text { loading }\end{array}$ & $\begin{array}{l}\text { Alpha/ } \\
\text { Variance }\end{array}$ & $\begin{array}{l}\text { Factor } \\
\text { loading }\end{array}$ & $\begin{array}{l}\text { Alpha/ } \\
\text { Variance }\end{array}$ & $\begin{array}{l}\text { Factor } \\
\text { loading }\end{array}$ & $\begin{array}{l}\text { Alpha/ } \\
\text { Variance }\end{array}$ & $\begin{array}{l}\text { Factor } \\
\text { loading }\end{array}$ & $\begin{array}{l}\text { Alpha/ } \\
\text { Variance }\end{array}$ & $\begin{array}{l}\text { Factor } \\
\text { loading }\end{array}$ & $\begin{array}{l}\text { Alpha/ } \\
\text { Variance }\end{array}$ & $\begin{array}{l}\text { Factor } \\
\text { loading }\end{array}$ & $\begin{array}{l}\text { Alpha/V } \\
\text { ariance }\end{array}$ \\
\hline $\begin{array}{l}\text { Business } \\
\text { Network }\end{array}$ & 0.57 & 0.42 & 0.40 & 0.38 & 0.67 & 0.29 & 0.42 & 0.28 & 0.66 & 0.19 & -0.23 & 0.29 & 0.60 & 0.41 \\
\hline $\begin{array}{l}\text { Research \& } \\
\text { Devt }\end{array}$ & 0.18 & 86.3 & -0.13 & 89.1 & - & 82.7 & 0.49 & 91.9 & 0.02 & 85.1 & -0.11 & 91.5 & 0.57 & 87.5 \\
\hline $\begin{array}{l}\text { Marketing } \\
\text { Strategy }\end{array}$ & 0.51 & & 0.70 & & 0.69 & & 0.70 & & 0.26 & & -0.23 & & 0.54 & \\
\hline $\begin{array}{l}\text { South Africa } \\
\text { Management }\end{array}$ & & & & & & & & & & & & & & \\
\hline $\begin{array}{l}\text { Accounting } \\
\text { Policy }\end{array}$ & 0.55 & & -0.24 & & - & & - & & 0.33 & & -0.13 & & 0.37 & \\
\hline $\begin{array}{l}\text { Organiz. } \\
\text { Structure }\end{array}$ & -0.09 & & - & & 0.46 & & - & & -0.37 & & 0.63 & & 0.51 & \\
\hline $\begin{array}{l}\text { Recruitment } \\
\text { Policy }\end{array}$ & 0.35 & 0.41 & - & 0.21 & - & 0.38 & - & - & - & 0.42 & 0.59 & 0.27 & 0.58 & 0.30 \\
\hline $\begin{array}{l}\text { Business } \\
\text { Network }\end{array}$ & 0.39 & 91.7 & 0.71 & 82.4 & 0.15 & 91.0 & - & - & 0.52 & 87.2 & 0.01 & 96.5 & 0.27 & 90.7 \\
\hline $\begin{array}{l}\text { Research } \\
\& \text { Devt }\end{array}$ & -0.15 & & 0.63 & & 0.46 & & - & & - & & -0.14 & & 0.43 & \\
\hline $\begin{array}{l}\text { Marketing } \\
\text { Strategy }\end{array}$ & 0.621 & & -0.205 & & 0.743 & & - & & 0.696 & & 0.471 & & 0.08 & \\
\hline $\begin{array}{l}\text { Both } \\
\text { Countries }\end{array}$ & & & & & & & & & & & & & & \\
\hline $\begin{array}{l}\text { Management } \\
\text { Accounting } \\
\text { Policy }\end{array}$ & 0.52 & & -0.42 & & - & & -0.24 & & 0.64 & & -0.27 & & 0.31 & \\
\hline $\begin{array}{l}\text { Organiz. } \\
\text { Structure }\end{array}$ & 0.19 & & 0.59 & & 0.08 & & -0.02 & & -0.17 & & 0.63 & & 0.46 & \\
\hline $\begin{array}{l}\text { Recruitment } \\
\text { Policy }\end{array}$ & 0.35 & 0.39 & - & 0.23 & -0.17 & 0.33 & -0.16 & 0.25 & - & 0.26 & 0.63 & 0.33 & 0.57 & 0.33 \\
\hline $\begin{array}{l}\text { Business } \\
\text { Network }\end{array}$ & 0.39 & 90.7 & 0.12 & 84.9 & 0.48 & 89.5 & 0.36 & 91.1 & 0.54 & 85.4 & -0.16 & 92.9 & 0.31 & 89.9 \\
\hline $\begin{array}{l}\text { Research } \\
\& \text { Devt }\end{array}$ & 0.09 & & 0.07 & & 0.46 & & 0.55 & & -0.07 & & -0.22 & & 0.48 & \\
\hline $\begin{array}{l}\text { Marketing } \\
\text { Strategy }\end{array}$ & 0.64 & & 0.68 & & 0.72 & & 0.70 & & 0.52 & & 0.22 & & 0.22 & \\
\hline
\end{tabular}

Source: Field work, 2018

Table 5. Cross-tabulation of management factors by selected business sectors in Nigeria \& South Africa.

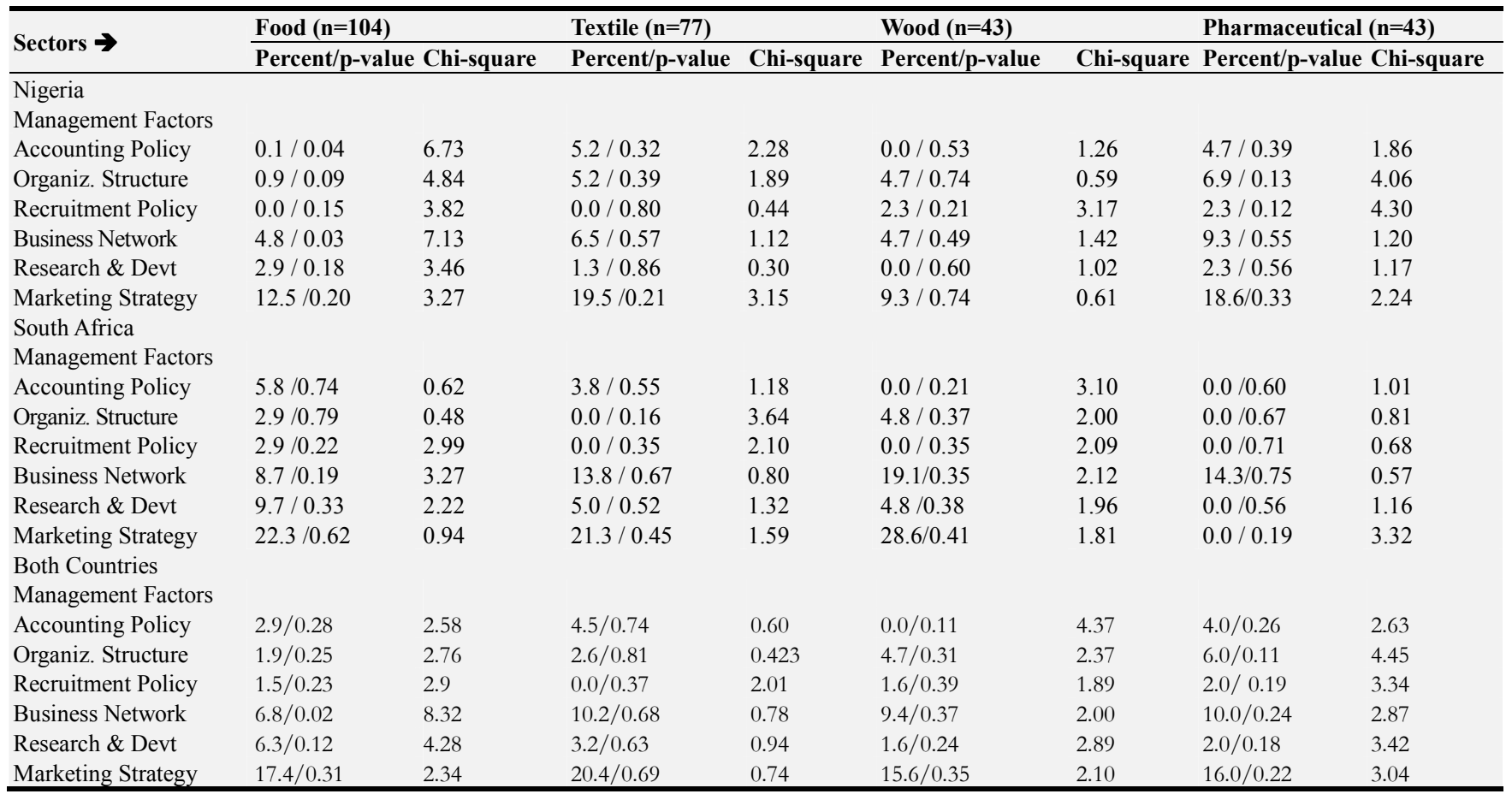


Table 5. Continued.

\begin{tabular}{|c|c|c|c|c|c|c|}
\hline \multirow{2}{*}{ Sectors $\rightarrow$} & \multicolumn{2}{|l|}{ Metal $(n=75)$} & \multicolumn{2}{|c|}{ Telecommunication $(n=74)$} & \multicolumn{2}{|l|}{ Services $(n=182)$} \\
\hline & Percent/p-value & Chi-square & Percent/p-value & Chi-square & Percent/p-value & Chi-square \\
\hline \multicolumn{7}{|l|}{ Nigeria } \\
\hline Management Factors & $2.7 / 0.79$ & 0.45 & $2.7 / 0.99$ & 0.02 & $2.8 / 0.95$ & 0.10 \\
\hline Accounting Policy & $0.0 / 0.23$ & 2.97 & $5.4 / 0.34$ & 2.15 & $1.7 / 0.52$ & 1.32 \\
\hline Organiz. Structure & $0.0 / 0.64$ & 0.89 & $1.4 / 0.52$ & 1.29 & $0.0 / 0.51$ & 1.37 \\
\hline Recruitment Policy & $17.3 / 0.06$ & 5.70 & $13.5 / 0.52$ & 1.31 & $11.5 / 0.62$ & 0.95 \\
\hline Business Network & $4.0 / 0.40$ & 1.84 & $2.7 / 0.93$ & 0.15 & $1.7 / 0.83$ & 0.37 \\
\hline Research \& Devt & $16.0 / 0.60$ & 1.01 & $13.5 / 0.98$ & 0.03 & $9.3 / 0.19$ & 3.31 \\
\hline \multicolumn{7}{|l|}{ South Africa } \\
\hline Management Factors & $4.0 / 0.77$ & 0.53 & $12.2 / 0.02$ & 7.76 & $4.4 / 0.04$ & 6.22 \\
\hline Accounting Policy & $4.0 / 0.75$ & 0.57 & $4.1 / 0.28$ & 2.53 & $3.2 / 0.04$ & 6.47 \\
\hline Organiz. Structure & $0.0 / 0.66$ & 0.82 & $2.0 / 0.29$ & 2.46 & $1.2 / 0.04$ & 6.03 \\
\hline Recruitment Policy & $16.0 / 0.77$ & 0.53 & $14.3 / 0.32$ & 2.27 & $13.5 / 0.03$ & 7.18 \\
\hline Business Network & $0.0 / 0.29$ & 2.48 & $14.3 / 0.03$ & 6.80 & $5.6 / 0.04$ & 6.58 \\
\hline Research \& Devt & $36.0 / 0.35$ & 2.08 & $16.3 / 0.08$ & 5.02 & $27.2 / 0.01$ & 9.19 \\
\hline \multicolumn{7}{|l|}{ Both Countries } \\
\hline Management Factors & $3.0 / 0.35$ & 2.09 & $6.5 / 0.11$ & 4.39 & $3.7 / 0.01$ & 8.64 \\
\hline Accounting Policy & $1.0 / 0.19$ & 3.28 & $4.9 / 0.15$ & 3.75 & $2.6 / 0.01$ & 8.71 \\
\hline Organiz. Structure & $0.0 / 0.24$ & 2.89 & $1.6 / 0.28$ & 2.53 & $0.7 / 0.01$ & 8.83 \\
\hline Recruitment Policy & $17.0 / 0.10$ & 4.64 & $13.8 / 0.34$ & 2.18 & $13.4 / 0.00$ & 11.73 \\
\hline Business Network & $3.0 / 0.30$ & 2.39 & 7.3/0.10 & 4.60 & $3.9 / 0.01$ & 8.7 \\
\hline Research \& Devt & $21.0 / 0.34$ & 2.16 & $14.6 / 0.19$ & 3.37 & $19.7 / 0.01$ & 9.94 \\
\hline
\end{tabular}

Note: significant at $\mathrm{p}<.05$

Source: Field work, 2018

Table 6 shows the results of the Principal Component Analysis used to identify the most crucial management factor(s) adopted in each sector. For both economies, the results showed the importance of the various combinations of management factors adopted in each sector, but when analyzed separately, the findings varied across countries. The results show that the crucial management factors needed for entrepreneurial activities in emerging economies are different. Also, that the management factors needed to boost entrepreneurial activities are peculiar to each economy, and different across sectors. In Nigeria, marketing strategy was the principal component in all except service sector whereas in South Africa, recruitment policy was the principal component in all the seven sectors.

\subsection{Comparison of the Findings at Each Level of Analysis}

The comparison was tackled concurrently in the examination of objectives one and two above. For the pooled data, however, marketing strategy was the principal component in four out of seven sectors.

Two factors (Organizational Structure and recruitment policy) were equally crucial in the telecommunication sector while accounting policy and recruitment policy were the principal components in metal and service sector, respectively. This implies that business owners in the telecommunication sector, who want their businesses to grow well, need to take cognizance of the organogram and recruitment policies adopted in running their businesses. Meanwhile, businesses in the metal and service sectors would need very good accounting policies and recruitment policies to enhance their businesses

Table 6. Principal component analysis of the management factors across business sectors in Nigeria \& South Africa.

\begin{tabular}{|c|c|c|c|c|c|c|c|c|c|c|c|c|c|c|}
\hline \multirow{2}{*}{$\begin{array}{l}\text { Business Sectors } \\
\rightarrow\end{array}$} & \multicolumn{2}{|l|}{ Food } & \multicolumn{2}{|l|}{ Textile } & \multicolumn{2}{|l|}{ Wood } & \multicolumn{2}{|c|}{ Pharmaceutical } & \multicolumn{2}{|l|}{ Metal } & \multicolumn{2}{|c|}{ Telecommunication } & \multicolumn{2}{|c|}{ Services } \\
\hline & Factor 1 & KMO & Factor 1 & KMO & Factor 1 & KMO & Factor 1 & KMO & Factor 1 & KMO & Factor 1 & KMO & Factor 1 & KMO \\
\hline Nigeria & & & & & & & & & & & & & & \\
\hline $\begin{array}{l}\text { Management } \\
\text { Factors }\end{array}$ & & & & & & & & & & & & & & \\
\hline Accounting Policy & 0.24 & & -0.11 & & -0.06 & & -0.04 & & 0.01 & & 0.29 & & 0.32 & \\
\hline $\begin{array}{l}\text { Organizational } \\
\text { Structure }\end{array}$ & 0.24 & & 0.09 & & 0.18 & & 0.14 & & 0.08 & & 0.37 & & 0.53 & \\
\hline $\begin{array}{l}\text { Recruitment } \\
\text { Policy }\end{array}$ & 0.16 & 51.2 & -0.10 & 52.7 & -0.06 & 51.8 & -0.08 & 52.4 & -0.11 & 52.7 & 0.22 & 52.4 & 0.61 & 54.5 \\
\hline Business Network & 0.64 & & 0.64 & & 0.62 & & 0.64 & & 0.67 & & 0.62 & & 0.45 & \\
\hline $\begin{array}{l}\text { Research \& } \\
\text { Development }\end{array}$ & 0.41 & & 0.62 & & 0.57 & & 0.57 & & 0.55 & & 0.51 & & 0.55 & \\
\hline $\begin{array}{l}\text { Marketing } \\
\text { Strategy } \\
\text { South Africa } \\
\text { Management } \\
\text { Factors }\end{array}$ & 0.76 & & 0.66 & & 0.75 & & 0.72 & & 0.72 & & 0.63 & & 0.39 & \\
\hline
\end{tabular}




\begin{tabular}{|c|c|c|c|c|c|c|c|c|c|c|c|c|c|c|}
\hline \multirow{2}{*}{$\begin{array}{l}\text { Business Sectors } \\
\rightarrow\end{array}$} & \multicolumn{2}{|l|}{ Food } & \multicolumn{2}{|l|}{ Textile } & \multicolumn{2}{|l|}{ Wood } & \multicolumn{2}{|c|}{ Pharmaceutical } & \multicolumn{2}{|l|}{ Metal } & \multicolumn{2}{|c|}{ Telecommunication } & \multicolumn{2}{|c|}{ Services } \\
\hline & Factor 1 & KMO & Factor 1 & KMO & Factor 1 & KMO & Factor 1 & KMO & Factor 1 & KMO & Factor 1 & КМO & Factor 1 & KMO \\
\hline Accounting Policy & 0.50 & & 0.45 & & 0.52 & & 0.49 & & 0.50 & & 0.46 & & 0.45 & \\
\hline $\begin{array}{l}\text { Organizational } \\
\text { Structure }\end{array}$ & 0.59 & & 0.58 & & 0.55 & & 0.55 & & 0.60 & & 0.62 & & 0.55 & \\
\hline $\begin{array}{l}\text { Recruitment } \\
\text { Policy }\end{array}$ & $0.64 \bullet$ & 59.8 & $0.66 \bullet$ & 58.0 & $0.62 \downarrow$ & 58.4 & 0.63 & 57.8 & 0.66 & 58.0 & $0.67 \bullet$ & 55.6 & 0.63 & 58.7 \\
\hline Business Network & 0.37 & & 0.33 & & 0.35 & & 0.36 & & 0.33 & & 0.28 & & 0.36 & \\
\hline $\begin{array}{l}\text { Marketing } \\
\text { Strategy }\end{array}$ & 0.43 & & 0.43 & & 0.40 & & 0.38 & & 0.37 & & 0.34 & & 0.45 & \\
\hline $\begin{array}{l}\text { Both Countries } \\
\text { Management }\end{array}$ & & & & & & & & & & & & & & \\
\hline Factors & & & & & & & & & & & & & & \\
\hline Accounting Policy & 0.65 & & -0.47 & & - & & -0.28 & & $0.74 \bullet$ & & -0.35 & & 0.40 & \\
\hline $\begin{array}{l}\text { Recruitment } \\
\text { Policy }\end{array}$ & 0.44 & 51.0 & - & 51.5 & -0.20 & 40.8 & -0.19 & 43.4 & - & 53.5 & $0.81 \bullet$ & 51.4 & 0.73 & 59.7 \\
\hline Business Network & 0.49 & & 0.14 & & 0.58 & & 0.42 & & 0.63 & & -0.21 & & 0.40 & \\
\hline $\begin{array}{l}\text { Research \& } \\
\text { Development }\end{array}$ & 0.11 & & 0.07 & & 0.55 & & 0.65 & & -0.08 & & -0.29 & & 0.61 & \\
\hline $\begin{array}{l}\text { Marketing } \\
\text { Strategy }\end{array}$ & $0.80 \diamond$ & & 0.76 & & 0.86 & & 0.84 & & 0.60 & & 0.28 & & 0.28 & \\
\hline
\end{tabular}

Note: The most crucial factors in bold with " $"$ sign

Source: Field work, 2018

\section{Conclusion}

The findings suggest that the management factors that enhance entrepreneurial activities differ across business sectors. Some management factors are also more crucial in some sectors than others. The results show that the crucial management factors needed to boost entrepreneurial activities are peculiar to each economy, and different across sectors. In Nigeria, marketing strategy was the principal component in all except service sector whereas in South Africa, recruitment policy was the principal component in all the seven sectors. For the pooled data, however, marketing strategy was the principal component in four out of seven sectors. Two factors (Organizational Structure and recruitment policy) were equally crucial in the telecommunication sector while accounting policy and recruitment policy were the principal components in metal and service sector, respectively

Consequently, it is averred that, any prospective entrepreneur or investor, seeking to set up businesses in these economies, must take cognizance of the peculiarities in each economy in order to enjoy the maximum benefits therein. Finally, this paper is a clarion call for more studies on the influence of management factors in some business sectors and especially for specific sectors of the economy.

\section{References}

[1] Argyres, N. S., and Silverman, B. S. 2004. R\&D, organization structure, and the development of corporate technological knowledge. Strategic Management Journal, 25 (8 - 9), 929-958.

[2] Barringer, M. W., and Milkovich, G. T. 1998. A Theoretical
Exploration of the Adoption and Design of Flexible Benefit Plans: A Case of Human Resource Innovation. Academy of Management Review, 305-324.

[3] Arthur, S. J., \& Hisrich, R. D. (2011). Entrepreneurship Through the Ages: Lessons Learned. Journal of Enterprising Culture, 19, 1-40.

[4] Hill, C. W., Jones, G. R., \& Schilling, M. A. (2014). Strategic management: theory: an integrated approach. Cengage Learning, 1-39.

[5] Timmons, J. A., and Bygrave, W. D. 1986. Venture Capital's Role in Financing Innovation for Economic Growth. Journal of Business Venturing, 1 (2), 161-176.

[6] Dollinger, M. J. 1984. Environmental Boundary Spanning and Information Processing Effects on Organizational Performance. Academy of Management Journal, 27 (2), 351-368.

[7] Jegede C. T., (2012) The Corporate Entrepreneurship and Performance among Manufacturing Firms in the South-Western Nigeria. Unpublished Ph. D. Thesis in Management and Accounting Department, Obafemi Awolowo University, Ile-Ife.

[8] Lewis, S. 2002. 'Family Friendly' Employment Policies: A Route to Changing Organizational Culture or Playing About at the Margins? Gender, Work and Organization, 4 (1), 13-23.

[9] Lewis, S., and Taylor, K. 1996. Evaluating the Impact of FamilyFriendly Employer Policies: A Case Study. The Work-Family Challenge: Rethinking Employment. London: Sage, 112-127.

[10] Besser, T. L., and Miller, N. 2011. The Structural, Social, and Strategic Factors Associated with Successful Business Networks. Entrepreneurship \& Regional Development, 23, 113-133

[11] Stevenson, H. H., and Jarillo, J. C. 1990. A Paradigm of Entrepreneurship: Entrepreneurial Management. Strategic Management Journal, 11 (5), 17-27. 
[12] Foss, N. J., and Klein, P. G. 2008. Entrepreneurship: From opportunity discovery to judgment. Center for Strategic Management and Globalization, Copenhagen Business School, Copenhagen.

[13] Foss, N. J., and Klein, P. G. 2005. Entrepreneurship and the economic theory of the firm: any gains from trade?. Handbook of entrepreneurship research, 55-80.

[14] Mathews, J. A. 2006. Strategizing, disequilibrium, and profit. Stanford University Press.

[15] Gray, C. 2002. Entrepreneurship, resistance to change and growth in small firms. Journal of Small Business and Enterprise Development, 9 (1), 61-72.

[16] Foss, N. J. 1997. Austrian Insights and the Theory of the Firm. In Advances in Austrian economics (pp. 175-198). Emerald Group Publishing Limited

[17] Holmstrom, B. R., and Tirole, J. 1989. The theory of the firm. Handbook of industrial organization, 1, 61-133.

[18] Bellis, M. 2014. The History of Coca-Cola. Retrieved from http://www.investors.about.com and http://www.worldofcocacola.com on $20^{\text {th }}$ September, 2017.

[19] Allen, F. 1994. Secret Formula: How Brilliant Marketing and Relentless Salesmanship Made Coca-Cola the Best-Known Product in the World. HarperCollins.

[20] Pendergrast, M. 2013. For god, country, and coca-cola. Basic Books.

[21] Chiaroni, D., Chiesa, V., and Frattini, F. 2011. The Open Innovation Journey: How firms dynamically implement the emerging innovation management paradigm. Technovation, 31 (1), 34-43.

[22] Huizingh, E. K. 2011. Open innovation: State of the art and future perspectives. Technovation, 31 (1), 2-9.

[23] Mahnke, V., Pedersen, T., and Venzin, M. 2005. The impact of knowledge management on MNC subsidiary performance: the role of absorptive capacity. MIR: Management International Review, 101-119.

[24] Ingram, P., and Silverman, B. S. 2000. Introduction: The new institutionalism in strategic management. In The new institutionalism in strategic management (pp. 1-30). Emerald Group Publishing Limited.

[25] Markham, J. W. 2015. A financial history of modern US corporate scandals: From Enron to reform. Routledge.

[26] Wennekers, S., and Thurik, R. 1999. Linking Entrepreneurship and Economic growth. Small Business Economics, 13, 27-55.

[27] Hebert, R. F., and Link, A. N. 1982. The EntrepreneurMainstream Views and Radical Critiques. New York: Praeger Publishers.

[28] Bartol, M. K., and Martin, D. C. 1994. Management (2nd Edition.). New York: McGraw-Hill Inc.

[29] Kelley, D. J., Singer, S., and Herrington, M. 2011. The Global Entrepreneurship Monitor: 2011 World Report (pp. 1-39).

[30] Katouzian, M. A. (1970). The development of the service sector: a new approach. Oxford Economic Papers, 22 (3), 362382.
[31] Bhojraj, S., Lee, C. M., \& Oler, D. K. (2003). What's my line? A comparison of industry classification schemes for capital market research. Journal of Accounting Research, 41 (5), 745774 .

[32] Mintzberg, H. 1979. The Structuring of Organizations: A Synthesis of the Research. University of Illinois, at UrbanaChampaign's Academy for Entrepreneurial Leadership Historical Research Reference in Entrepreneurship.

[33] Morton, N. A., and Hu, Q. 2008. Implications of the Fit Between Organizational Structure and ERP: A Structural Contingency Theory Perspective. International Journal of Information Management, 28 (5), 391-402.

[34] Donaldson, L. 2001. The Contingency Theory of Organizations: Sage Publications, Incorporated.

[35] Dess, G. G., and Davis, P. S. 1984. Porter's 1980 Generic Strategies as Determinants of Strategic Group Membership and Organizational Performance. Academy of Management Journal, 467-488.

[36] Carroll, G. R. 1993. A Sociological View on Why Firms Differ. Strategic Management Journal, 14 (4), 237-249.

[37] Shane, S. A. 2003. A General Theory of Entrepreneurship: The Individual-Opportunity Nexus: Edward Elgar Pub.

[38] Littunen, H. 2000. Entrepreneurship and the Characteristics of the Entrepreneurial Personality. International Journal of Entrepreneurial Behaviour and Research, 6 (6), 295-310.

[39] Zahra, S. A., and Bogner, W. 2000. Technology Strategy and Software New Ventures' Performance: Exploring the Moderating Effect of the Competitive Environment. Journal of Business Venturing, 15 (2), 135-173.

[40] Enkel, E., Gassmann, O., \& Chesbrough, H. 2009. Open R\&D and open innovation: exploring the phenomenon. $R \& d$ Management, 39 (4), 311-316.

[41] Singh, S., Simpson, R., Mordi, C., and Okafor, C. 2011. Motivation to Become an Entrepreneur: A Study of Nigerian Women's Decisions. African Journal of Economic and Management Studies, 2 (2), 202-219.

[42] Tijani, A. A., Oyeniyi, G. O., and Ogunyomi, O. O. 2012. The Impact of Technical Entrepreneurial Skills on Employment Generation in Small and Medium Scale Enterprises in Lagos State, Nigeria: A Comparative Analysis. European Journal of Humanities and Social Sciences, 13 (1).

[43] Urban, B. 2009. Opportunity Recognition: Delineating the Process and Motivators for Serial Entrepreneurs. South African Journal of Economic and Management Sciences 12 (4), 513-532.

[44] Callaghan, C., and Venter, R. 2011. An Investigation of the Entrepreneurial Orientation, Context and Entrepreneurial Performance of Inner-City Johannesburg Street Traders. Southern African Business Review 15 (1), 28-49.

[45] Coviello, N. E., and Jones, M. V. 2004. Methodological Issues in International Entrepreneurship Research. Journal of Business Venturing, 19 (4), 485-508.

[46] Briggs, B. R. 2009. Issues Affecting Ugandan Indigenous Entrepreneurship in Trade. African Journal of Business Management, 3 (12), 786-797. 
[47] Afrin, S., Islam, N., and Ahmed, S. U. 2008. A multivariate Model of Micro Credit and Rural Women Entrepreneurship Development in Bangladesh. International Journal of Business and Management, 3 (8), P169.

[48] Cronbach, L. 1951. Coefficient Alpha and The Internal Structure of Tests. Psychometrika, 16 (3), 297-334.

[49] Santos, J. R. A. 1999. Cronbach's Alpha: A Tool for Assessing the Reliability of Scales. Journal of Extension, 37 (2).
[50] Bhattacherjee, A. 2012. Social Science Research: Principles, methods, and practices (2nd Edition.): USF Tampa Bay Open Access Textbooks Collection. Book 3.

[51] Schumpeter, J. A. 1952. Can Capitalism Survive? New York: Harper and Row.

[52] Drucker, P. F. 1994. The Theory of the Business. Harvard business review, 72 (5), 95-104 